\title{
Phosphorus and energy flows through the food system of Brussels Capital Region
}

\author{
Anastasia Papangelou*1, Wouter M.J. Achten ${ }^{2}$ and Erik Mathijs ${ }^{1}$ \\ ${ }^{1}$ KU Leuven, Department of Earth and Environmental Sciences, Celestijnenlaan 200E, 3001 Leuven, \\ Belgium \\ ${ }^{2}$ Université Libre de Bruxelles (ULB), Institute for Environmental Management and Land-use \\ Planning, Av. F.D. Roosevelt 50, 1050 Brussels, Belgium \\ * Corresponding author : anastasia.papangelou@kuleuven.be
}

\begin{abstract}
Urban food systems are linear and wasteful. Strategies towards more circular food systems need to be adopted; however, what these strategies may be and what effects they may have on other urban systems is not well documented. With this study, we offer a systemic representation of the Brussels Capital Region food system through mapping its phosphorus and energy flows, and we evaluate the effect that three theoretical scenarios will have on these flows, and on the circularity level of the system. The results show that the Brussels food system is strongly linear and that no more than $2 \%$ of the incoming $\mathrm{P}$ can currently be reused within the city. Food waste valorization and sewage sludge utilization can increase the amount of $\mathrm{P}$ available for reuse without negatively affecting the net amount of electricity recovered. The amount of $\mathrm{P}$ available in the urban effluents can theoretically cover the demand for mineral $\mathrm{P}$ in the agricultural systems of the two neighboring Brabant provinces. The regulatory framework for the reuse of urban effluents is, however, hostile and it is still to be determined whether there is a demand for re-introducing these $P$ flows in the agri-food system that feeds Brussels.
\end{abstract}

\section{Keywords}

Circular economy, urban food system, nutrients, material flow analysis (MFA)

This is the accepted manuscript of the article published in Resources, Conservation \& Recycling: https://doi.org/10.1016/j.resconrec.2020.104687

(C) 2020. This version of the manuscript is made available under the CC-BY-NCEY NC ND ND 4.0 license http://creativecommons.org/licenses/by-nc-nd/4.0/ 


\section{Introduction}

Cities have an important role to play in the transition towards a Circular Economy (CE) for food. Food consumption is among the top three drivers of urban environmental footprints (Goldstein et al., 2017) and urban consumption is projected to mount up to $80 \%$ of all food produced by 2050 (EMF, 2019). This concentration of consumption in cities suggests the parallel concentration of human excreta and, partially, food waste in them. Subsequently, cities can influence decisions on what and how the agri-food system produces and at the same time drive efforts to avoid, reuse and ultimately phase out waste in the system.

Food cannot grow without supplying it with nutrients, like nitrogen $(\mathrm{N})$, phosphorus $(\mathrm{P})$, and potassium (K). At the same time, the overuse of mineral NPK fertilizers and the disposal of untreated, nutrient-rich urban effluents in aquatic bodies causes the eutrophication of terrestrial and aquatic ecosystems and affects the quality of the agricultural soil (Smil, 2000). While $\mathrm{N}$ is available everywhere around us, mineral $\mathrm{P}$ fertilizers are made from phosphate rock, which is a finite resource (Cordell et al., 2009). This double status of phosphorus, as a pollutant and a scarce resource, makes phosphorus management a prominent strategy in the context of the circular bioeconomy, and so circular food systems (Nesme and Withers, 2016; Withers et al., 2018).

In order to better manage phosphorus we first need to understand how it flows through coupled human-environmental systems, where it comes from, where it leaks worst, and where the biggest potentials for reuse lie. Indeed, lots of research has been dedicated in the past decade to map P flows in cities, regions and countries. Up to this point, detailed $\mathrm{P}$ budgets are available for cities in Sweden (Kalmykova et al., 2012; Schmid Neset et al., 2008; Wu et al., 2016), China (Li et al., 2010; Lin et al., 2016; Ma et al., 2014; Qiao et al., 2011) and Canada (Metson and Bennett, 2015; Treadwell et al., 2018). Phosphorus follows similar paths in these cities: it enters through imported food and it either exits with sewage sludge and solid organic waste or accumulates in urban sinks, such as soils and landfills. (Chowdhury et al., 2014; Kalmykova et al., 2012). In some cases, smaller quantities of treated sewage sludge or composted organic waste are recycled in urban agriculture, e.g. (Metson and Bennett, 2015), or in agriculture outside the system boundaries, e.g. (Ma et al., 2014; Wu et al., 2016). The anthropogenic phosphorus cycle, is thus, closely connected to the food cycle, making $\mathrm{P}$ an adequate 'trace element' to represent flows related to the food system, e.g. food products, food waste and human excrements.

Besides food, phosphorus management involves and influences the water, energy and waste management sub-systems in a city. Researchers have addressed the nutrient, and thus phosphorus, management from such a nexus perspective, by studying nitrogen or phosphorus along with other resources, such as water (Esculier et al., 2018), energy (Hamilton et al., 2015) or both (Liang et al., 2019; Villarroel Walker et al., 2014; Villarroel Walker and Beck, 2012). These studies are, however, on a regional (Villarroel Walker and Beck, 2012) or national (Hamilton et al., 2015) scale. So far, few studies have taken a multi-resource perspective when studying nutrients at the urban scale (Liang et al., 2019; Ma et al., 2014; Villarroel Walker et al., 2014) and they show 
trade-offs between different nutrient management scenarios, depending on various objectives and priorities (Villarroel Walker et al., 2014).

Brussels, the capital of Belgium, is currently considering alternatives for treating its inhabitants' kitchen waste that is collected separately in the dedicated orange bag since 2017, on a voluntary basis. The small amounts of kitchen waste collected are currently sent to an Anaerobic Digestion (AD) plant $130 \mathrm{~km}$ West of the capital, while Brussels' authorities are investigating solutions for the management of its organic waste (De Muynck et al., 2019). The regional government has been favoring the installation of an AD plant within the city (Bortolotti et al., 2018b). An important motivation behind prioritizing $\mathrm{AD}$ seems to be a policy focus on green energy, in a national effort to reach the EU 2020 targets. Nonetheless, Waste-to-Energy (WtE) strategies are further down the food material hierarchy pyramid than prevention and reuse solutions (WRAP, 2016), and can potentially be at odds with other programs, such as the city's Good Food strategy (Ronsmans, 2015) or the regional program for a Circular Economy (Anon, 2016).

Given the scarcity of multi-resource flows analyses at the urban scale and the importance of the interaction between phosphorus and energy from a CE perspective, as the Brussels case exemplifies, the research objectives of this study are:

(i) to identify and quantify the phosphorus flows in Brussels that are potentially available for recovery and reuse and assess the current $\mathrm{P}$ circularity of the food system, and

(ii) to evaluate circular solutions towards better resource management in the food system from a multi-resource perspective, accounting for phosphorus and energy simultaneously.

\section{Materials \& Methods}

\subsection{Case Study : Brussels Capital Region (BCR)}

Brussels Capital Region (BCR) is one of the three regions that constitute Belgium, along with Flanders in the north and Wallonia in the south. It has a population of 1'163'486 (2014) and a surface area of $161 \mathrm{~km}^{2}$ (IBSA, 2015). Despite its administrative 'regional' status, BCR is not a city-region as meant in planning (Rodríguez-Pose, 2008): it does not encompass the whole metropolitan area of Brussels, nor does it include the peri-urban and rural hinterlands of the city. It has the status of a region for political reasons, but its character is urban, with a population density of $>$ 7'000 cap $/ \mathrm{km}^{2}$ (IBSA, 2015). Finally, BCR is not to be confused with the City of Brussels, which is one of the 19 municipalities that together form BCR (Figure 1). In the rest of the paper we use the terms city, Brussels and BCR interchangeably to refer to BCR.

The city's economy is predominantly based on the service sector. Agricultural production is marginal, with 1'850 ha, $1 \%$ of total area, cultivated in 2014 mainly with cereals, potatoes, and sugar beets (StatBel, 2014). In economic terms, the contribution of the primary sector to the city's economy is negligible (IBSA, 2015). Although many industries have their headquarters in Brussels, hardly any actual manufacturing activities take place within the city's boundaries. The 
secondary sector in the city mainly consists of small-scale food processing, i.e. bakeries and pastry shops (RDC-Environment, 2014).

Food waste is collected together with mixed waste and is incinerated. Since 2017, the inhabitants of Brussels have also had the option of sorting their food waste, which is then collected separately and sent to an anaerobic digestion plant in Ypres, West Flanders. Green waste is collected separately and composted, either in a facility in the south of Brussels (BruxellesCompost) or in composting plants in the surrounding areas. Finally, wastewater is treated in two wastewater treatment plants (WWTP): the South WWTP, established in 2000 and currently under modernization and the North WWTP, in operation since 2007. Brussels has a combined sewer network that serves both the transport of domestic wastewater to the two treatment plants and the runoff drainage. The Northern plant currently receives app. $3 / 4$ of the domestic wastewater generated in BCR; the Southern plant treats the rest, together with some industrial effluents (IBGE, 2012; SBGE, 2017).

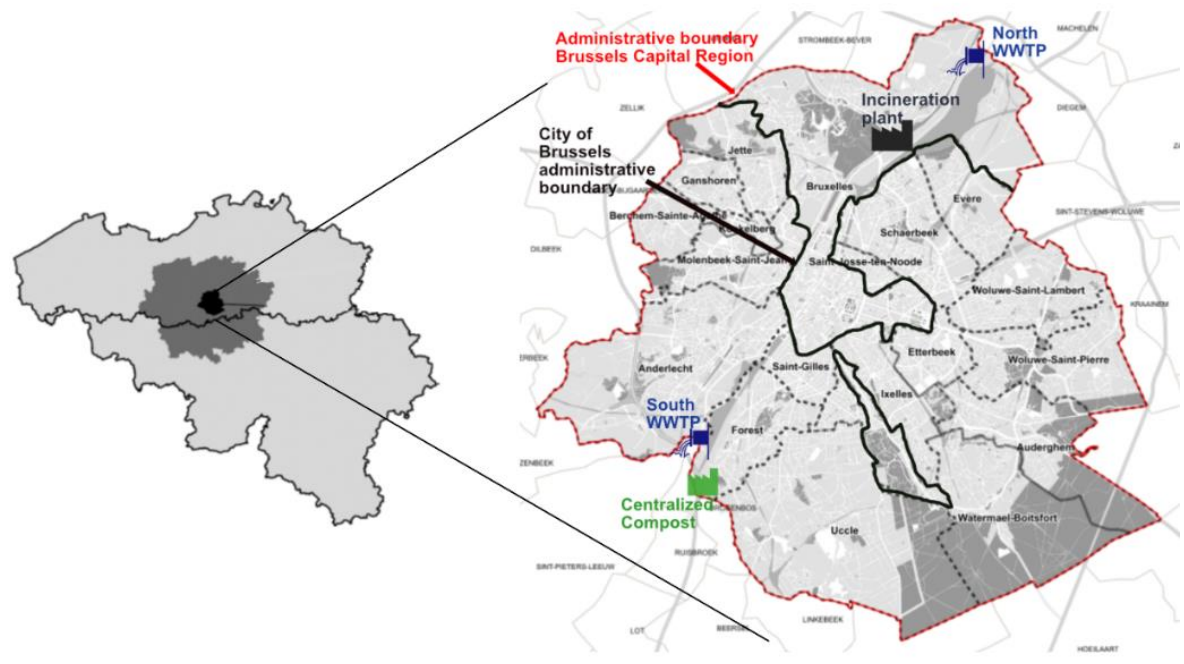

Figure 1 Left: map of Belgium (light grey), including the metropolitan area of Brussels (dark grey) and BCR (black). Right: map of BCR, with the locations of the wastewater treatment plants (WWTPs), the incinerator and the composting facility. The administrative regional boundary is indicated in red, the boundary of the City of Brussels in solid black and the rest of the communes in dashed grey lines. [Sources : left: (Athanassiadis et al., 2016), base map right: BruGIS; icons: Factory by Fahmihorizon from the Noun Project; Outfall by Luis Prado from the Noun Project]

\subsection{Methodology}

\subsubsection{System definition}

The system under study is the food system within the administrative boundary of the Brussels Capital Region (Figure 2); it corresponds roughly to the activity "to nourish" in the city (Baccini and Brunner, 2012). The reference year is 2014, the most recent year for which all data were available. For variables that vary from year to year, like the amounts of wastewater treated or the process energy inputs in the incinerator, we used 5-year averages to ensure that the model is as representative of the current situation as possible. 
Within the food system, we can distinguish 4 subsystems: production, trade and consumption, wastewater management, and municipal solid waste (MSW) management. The 'production' subsystem refers primarily to the process Urban Soils, including private and communal gardens, agricultural lands and public green spaces, like parks and forests. We consider the process 'Decentralized Composting' to be part of the 'production' sub-system too, since it operates separately from the centralized MSW management system and is closely connected to the urban soil. The food processing industry, mostly bakeries and chocolatiers that sell largely outside of BCR, was excluded due to lack of data, which leads to an underestimation of both inputs and outputs. Table 1 list the goods considered in this study and their definitions, as well as the main flows within each good category.

In our study we adopt the multi-layer Substance Flow Analysis framework described in (Hamilton et al., 2015) to quantify the phosphorus and energy flows in Brussels' food system. For energy, we distinguish between gross energy $\left(\mathrm{GE}_{\mathrm{f}}\right)$ that represents the chemical energy content of the material flow $\mathrm{f}$, and $\mathrm{PE}_{\mathrm{p}}$ that represents the in- or outflows of energy (electricity, fuel, heat) to or from process $\mathrm{p}$. To estimate the GE of the flows we use the calorific content for the different food items, and the lower heating value (LHV) or net calorific content for all other flows. We do not account for transport, due to data gaps; however, in section 4.1 we discuss qualitatively some effects of accounting for transport to the energy flows.

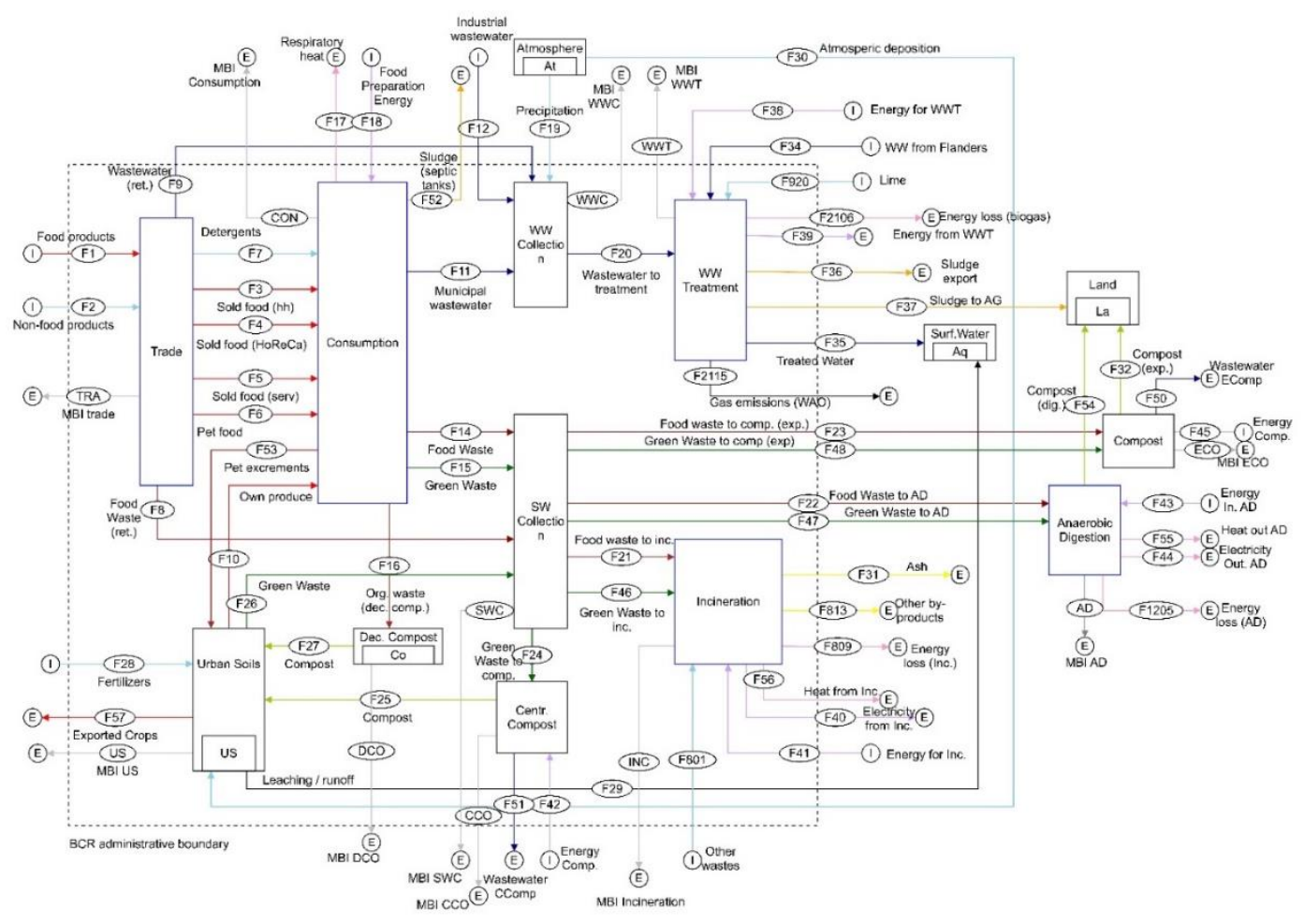

Figure 2 System diagram : the food and phosphorus system in Brussels Capital Region. Flows are colored according to the 'good' category they belong to (see Table 1 and Table 2 for key). 


\subsubsection{Quantification of flows}

\section{Trade and consumption}

We estimate the total input of food into the system as the sum of the food consumed in Brussels and the food waste generated during consumption and trade (Eq.1). Data on the daily per capita consumption of different food items come from the latest national Food Consumption Survey(Ridder et al., 2016) and their corresponding phosphorus and energy contents from the Belgian database internubel (Nubel, 2018) or Dutch database NEVO (RIVM, 2016). Based on information on the place of consumption from the Food Consumption Survey (Ost, 2015), we can differentiate between the food consumed at home, at restaurants and cafés (HoReCa), and at school and work canteens (services). We assume that visitors have the same daily food intake as the inhabitants, and that they consume all their meals in a HoReCa establishment. In order to quantify the food consumed by incoming commuters, we assume that they have their lunch, corresponding to $1 / 3$ of the daily intake, at a work canteen. We use the net number of incoming commuters, to account for the food consumed outside Brussels by the outgoing commuters. Details on the calculation are given in SI (Data In Brief paper).

Non-food products include detergents and cosmetics and pet food. For the former, we use the value for the specific P detergent consumption in Belgium by (Ott and Rechberger, 2012). Phosphorus in pet food is calculated using official statistics for the number of cats and dogs in Brussels (Statbel, 2018) and literature values for their daily P intakes (Wu et al., 2016).

Food waste generation from households, HoReCa, services, and trade is estimated based on (Zeller et al., 2019) and their P and energy content from literature values (Table 1 and Table S1). The total imports of food (F1) and non-food products (F2) into trade are approximated as the sum of sold products (F3 - F7) and waste of the food trade sector (F8) from (Zeller et al., 2019).

This probably underestimates the values of the import flows and gives an idealized impression of 'Trade' as a tight process. Including trade data, however, would require the combination of national data on international trade with the interregional Input-Output (IO) tables, the translation of IO data in physical quantities and their disaggregation to food product or food group level, and the adoption of assumptions for the shares of food that are re-exported and used for processing. Given the additional uncertainties and complexity that these data treatment steps would introduce to the model, we opted for using the mass balance to calculate the import flows.

Further details on the calculation, assumptions and data sources can be found in Table 1 and the SI.

Food Sold $=$ Food Consumed + Food Waste

$$
=F C_{\text {inh }}+F C_{\text {vis }}+F C_{\text {com,net }}+\left(F W_{h h}+F W_{\text {HoR }}+F W_{\text {serv }}\right)
$$

$\mathrm{FC}_{\mathrm{i}}$ : food consumed by inhabitants (inh), visitors (vis), or net number of commuters (com,net)

$\mathrm{FW}_{\mathrm{j}}$ : food waste generated by households (hh), HoReCa (HoR), or services (serv)

We assume that $98 \%$ of the $\mathrm{P}$ intake by humans and $100 \%$ of the $\mathrm{P}$ intake by pets ends up in their excrements; in addition, we adopt the assumption by Theobald and colleagues (2016) in their 
analysis of the $\mathrm{P}$ flows in Berlin-Bradenburg, that $60 \%$ of the pet excrements end up directly in the soil (F53), whereas the rest $40 \%$ is disposed of in the household waste

\section{- Production}

Food production activities in Brussels include both urban agriculture (UA) and conventional crop production. UA represents private and communal gardening and small-scale professional horticultural activities, actual production data for which are scarce and uncertain, e.g. (Boutsen et al., 2018). According to a recent comprehensive study of Brussels' urban metabolism, a maximum $1 \%$ of the vegetable consumption in Brussels could be covered by soil-based horticulture within the city, whereas half of the exploitable lands were used for horticulture in 2010 (EcoRes sprl et al., 2015, p. 95). We thus estimate the amounts of food produced in UA and consumed directly by inhabitants (F10, 'Own produce') to represent $0.5 \%$ of the total plant-based products consumed. Conventional agricultural production data are taken from official statistics (StatBel, 2014). We use the average mineral-P application rate of the Walloon region (REEW, 2018) and official manure export statistics of Flanders (VLM, 2014) to estimate synthetic fertilizer and manure inputs (F28). Details on the calculations are given in the SI.

Given the study's focus on nutrient circularity and the tight connection between UA and decentralized compost (household and neighborhood scale) we classify the latter within the 'production' sub-system. Around 420 tonnes of household food waste were composted in private and communal composting sites in 2015 (F16), representing $0.4 \%$ of the total food waste production (Bortolotti et al., 2018a).

\section{- Wastewater Management}

Primary data on the amounts of wastewater treated in the two WWTPs (F20, F34, F35) and their characteristics come from the annual reports of Brussels Society for Water Management (SBGE, n.d.), datasets from Brussels' environmental agency (IBGE, 2018a), and the webpage of Aquiris, the company that operates the North WWTP. Information and data on the sludge treatment process (F36, F37) were taken from (Chauzy et al., 2010) and assumed to represent the situation in both WWTPs. For the estimation of the process energy (F38, F39) we combined literature values with those provided online by the operator (AQUIRIS, n.d.). The anaerobic digestion of sewage sludge and the energy recovery from biogas were modelled following (Cano et al., 2015). Details on the modelling process, the variables used and their sources, as well as the underlying assumptions can be found in the SI.

\section{- Municipal Solid Waste Management}

Data on the amounts of food and green waste to the different treatment options (F21 - 24, F46 - 48) come from a recent study by Zeller et al. (2019). Incineration is the main treatment option for MSW in Brussels. Amounts of incineration by-products (F31, F813) were calculated with information from the annual reports of Bruxelles-Proprété, the agency managing the incinerator (ABP, n.d.); the same reports, combined with the energy balance of Brussels (IBGE, 2015), were used to estimate the energy flows (F40, F41, F56, F809). When primary data were missing, the most recent life cycle inventory (LCI) data available were used (Haupt et al., 2018). 
Household green waste collected separately by ABP is composted in the only large-scale composting plant in Brussels (process 'Centralized Compost' - CCO). Compost from CCO is mainly used for landscaping across the city (Robinet, 2019), thus we assume that all of the P content is returned to Urban Soils.

\section{- Mass Balance Inconsistencies}

Different data sources of variable quality were used for the calculation of the different flows: primary data were available in certain cases, while in others we had to rely either on data referring to the whole country (e.g. food consumption), or another region in the country (e.g. characteristics of compost in Flanders), modeled data from other studies on Brussels (e.g. organic waste streams), design values for some processes (e.g. sludge generation and energy consumption in the North WWTP) or general values from textbooks and peer-reviewed literature ( $\mathrm{P}$ and energy content for most of the flows). The main data sources used are listed in Table 1 and Table 2 and a comprehensive list can be found in the SI.

Given the great variability of data origins and quality, we chose to follow the method of Hamilton et al. (2015), and get an idea of uncertainties by calculating the mass balance inconsistencies for each process and keeping them visible in the model. This approach works in this case, since we did not reconcile the data in the model and the input and outputs flows in the different processes were either (i) estimated independently (e.g. Consumption, Wastewater Collection) or (ii) modelled using transfer coefficients and assumptions from actual facility-level data (e.g. WWT, incineration), or general literature (e.g. energy flows in WWT and AD). The only exception to this procedure is the system input flows F1 (Food products) and F2 (non-food products), which are simply the sum of the output flows from the process 'Trade'. We include 'Trade' as a process separate from consumption in the system, in order to account for the food waste generated by it; however, it is mostly a 'proxy process' and its input flows should be interpreted with care.

Table 1 Types of goods (materials) included in the system, color key for Fig.1 and main data sources for the estimations of their phosphorus (P) and gross energy (GE) content (hh : households, prof : professional, ser : services, AD : anaerobic digestion, WWT : wastewater treatment)

\begin{tabular}{|c|c|c|c|c|}
\hline Good & Color & Description & Flows & $\begin{array}{l}\text { Main source of P \& GE } \\
\text { content for good }\end{array}$ \\
\hline $\begin{array}{l}\text { Food } \\
\text { products }\end{array}$ & Red & $\begin{array}{l}\text { Food products imported and } \\
\text { sold within BCR and crop } \\
\text { production }\end{array}$ & $\begin{array}{l}\text { F1 : Food products } \\
\text { F3 : Sold food to hh } \\
\text { F4 : Sold food to HoReCa } \\
\text { F5 : Sold food to services } \\
\text { F10 : Own produce } \\
\text { F57 : Exported Crops }\end{array}$ & $\begin{array}{l}\text { (Le Noë et al., 2017; } \\
\text { Nubel, 2018; RIVM, 2016) }\end{array}$ \\
\hline $\begin{array}{l}\text { Non-food } \\
\text { products }\end{array}$ & $\begin{array}{l}\text { Light } \\
\text { blue }\end{array}$ & $\begin{array}{l}\text { Detergents, cosmetics, } \\
\text { fertilizers and pet food } \\
\text { imported and sold within } \\
\text { BCR }\end{array}$ & $\begin{array}{l}\text { F2 : Non-food products } \\
\text { F6 : Pet food } \\
\text { F7 : Detergents \& cosmetics } \\
\text { F28: Fertilizers }\end{array}$ & $\begin{array}{l}\text { (Ott and Rechberger, 2012; } \\
\text { VLM, 2014; Wu et al., } \\
\text { 2016) }\end{array}$ \\
\hline $\begin{array}{l}\text { Organic } \\
\text { waste }(\mathrm{OW})\end{array}$ & $\begin{array}{l}\text { Brow } \\
n\end{array}$ & $\begin{array}{l}\text { OFMSW, mixed FW and } \\
\text { GW, pet excrements to soil }\end{array}$ & $\begin{array}{l}\text { F16 : OW to dec.compost } \\
\text { F53 : Pet excrements to soil }\end{array}$ & (Fisgativa et al., 2016) \\
\hline
\end{tabular}


Table 1 (cont'd)

\begin{tabular}{|c|c|c|c|c|}
\hline Good & Color & Description & Flows & $\begin{array}{l}\text { Main source of P \& GE } \\
\text { content for good }\end{array}$ \\
\hline $\begin{array}{l}\text { Food waste } \\
(\text { FW) }\end{array}$ & $\begin{array}{l}\text { Dark } \\
\text { red }\end{array}$ & $\begin{array}{l}\text { Inedible parts of food } \\
\text { products and wasted food } \\
\text { (gone bad \& meals leftovers) } \\
\text { from households, HoReCa } \\
\text { and canteens (services) }\end{array}$ & $\begin{array}{l}\text { F14: Food waste from consumption } \\
\text { F8 : Food waste from trade } \\
\text { F21 : Food waste to incineration } \\
\text { F22: Food waste to AD } \\
\text { F23: Food waste export to compost }\end{array}$ & $\begin{array}{l}\text { (Fisgativa et al., 2016; } \\
\text { Jensen et al., 2016) }\end{array}$ \\
\hline $\begin{array}{l}\text { Green waste } \\
(\text { GW) }\end{array}$ & Green & $\begin{array}{l}\text { Garden waste from } \\
\text { households and green waste } \\
\text { from parks and public spaces }\end{array}$ & $\begin{array}{l}\text { F15: Household green waste } \\
\text { F24 : Green waste to compost } \\
\text { F26 : Professional green waste } \\
\text { F46 : Green waste to incineration } \\
\text { F47 : Green waste to AD } \\
\text { F48 : Green waste export to compost }\end{array}$ & $\begin{array}{l}\text { (Boldrin and Christensen, } \\
\text { 2010) }\end{array}$ \\
\hline Compost & $\begin{array}{l}\text { Lime } \\
\text { green }\end{array}$ & $\begin{array}{l}\text { Compost from all scales } \\
\text { (household, neighborhood, } \\
\text { big scale) and all kinds of } \\
\text { feed (OW, GW, digestate) }\end{array}$ & $\begin{array}{l}\text { F25: Compost to gardens \& parks } \\
\text { F27: Compost to private gardens } \\
\text { F32 : Compost (from exp.) } \\
\text { F54 : Compost from digestate \& GW }\end{array}$ & $\begin{array}{l}\text { (Möller et al., 2018; Vlaco, } \\
\text { n.d.) }\end{array}$ \\
\hline $\begin{array}{l}\text { Wastewater } \\
\text { (ww) }\end{array}$ & $\begin{array}{l}\text { Dark } \\
\text { blue }\end{array}$ & $\begin{array}{l}\text { Municipal and industrial } \\
\text { wastewater flows and treated } \\
\text { water discharged in the } \\
\text { Senne }\end{array}$ & $\begin{array}{l}\text { F11: Municipal wastewater to sewers } \\
\text { F12 : Industrial wastewater to WWT } \\
\text { F20 : Wastewater from BCR to WWT } \\
\text { F34 : ww from Flanders to WWT } \\
\text { F35 : Treated water to Senne } \\
\text { F50 : ww from compost (exp.) } \\
\text { F51 : ww from centralized compost }\end{array}$ & (IBGE, 2018a; SBGE, n.d.) \\
\hline $\begin{array}{l}\text { Sewage } \\
\text { sludge (SS) }\end{array}$ & $\begin{array}{l}\text { Orang } \\
\text { e }\end{array}$ & $\begin{array}{l}\text { Raw sewage sludge (from } \\
\text { WWT and septic tanks) and } \\
\text { products from sewage sludge } \\
\text { treatment (e.g. technosands) }\end{array}$ & $\begin{array}{l}\text { F52: Septic sludge } \\
\text { F36 : Treated sludge from S.WWTP } \\
\text { F37 : Treated sludge from N.WWTP }\end{array}$ & $\begin{array}{l}\text { (Chauzy et al., 2010; } \\
\text { IBGE, 2018a; SBGE, n.d.) }\end{array}$ \\
\hline $\begin{array}{l}\text { Incineration } \\
\text { by-products }\end{array}$ & $\begin{array}{l}\text { Yello } \\
\mathrm{w}\end{array}$ & $\begin{array}{l}\text { Ash (bottom \& fly) and rest } \\
\text { (metals, slug, salts) }\end{array}$ & $\begin{array}{l}\text { F31: Bottom and fly ash } \\
\text { F813: Other incineration by-products }\end{array}$ & $\begin{array}{l}\text { (ABP, n.d.; Haupt et al., } \\
2018)\end{array}$ \\
\hline $\begin{array}{l}\text { Emissions } \\
\text { (gas \& } \\
\text { liquid) }\end{array}$ & Black & $\begin{array}{l}\text { P gas or aqueous emissions } \\
\text { not accounted for in other } \\
\text { flows }\end{array}$ & $\begin{array}{l}\text { F29: Leaching \& runoff } \\
\text { F2115: Gaseous emissions WAO }\end{array}$ & $\begin{array}{l}P \& G E \text { content assumed } \\
\sim 0\end{array}$ \\
\hline
\end{tabular}

Table 2 Process energy flows included in the model, color key for Fig.1 and main data sources for their estimations

\begin{tabular}{|c|c|c|c|c|}
\hline Process Energy & Color & Description & Flows & Main sources \\
\hline Electricity & Violet & $\begin{array}{l}\text { Electricity process } \\
\text { inputs and outputs }\end{array}$ & $\begin{array}{l}\text { F18 : Food preparation energy } \\
\text { F38 : Energy input WWT } \\
\text { F39 : Energy output WWT } \\
\text { F40 : Electricity output (incineration) } \\
\text { F41 : Electricity input (incineration) } \\
\text { F42 : Electricity for centralized compost } \\
\text { F45 : Energy for centralized compost (e) } \\
\text { F43 : Energy input AD } \\
\text { F44 : Electricity output AD }\end{array}$ & $\begin{array}{l}\text { (IBGE, 2017a, 2015) } \\
\text { (Aquiris, n.d.) } \\
\text { (Cano et al., 2015) } \\
\text { modelled } \\
\text { (IBGE, 2019) } \\
\text { (Haupt et al., 2018) } \\
\text { (Haupt et al., 2018) } \\
\text { (Haupt et al., 2018) } \\
\text { modelled }\end{array}$ \\
\hline Heat & Pink & $\begin{array}{l}\text { Heat process inputs } \\
\text { and outputs (incl. } \\
\text { energy losses) }\end{array}$ & $\begin{array}{l}\text { F17 : Respiratory heat } \\
\text { F2106: Energy loss from biogas (WWT) } \\
\text { F56 : Heat output (incineration) } \\
\text { F809:Energy loss from incinerator } \\
\text { F55: Heat output AD } \\
\text { F1205: Energy loss from digester }\end{array}$ & $\begin{array}{l}\text { balance } \\
\text { Modeled based on } \\
\text { (Cano et al., 2015) \& } \\
\text { (Haupt et al., 2018) }\end{array}$ \\
\hline
\end{tabular}




\subsubsection{Scenarios}

In order to illustrate the potential for phosphorus reuse and reveal trade-offs between phosphorus availability and energy use, we compare 4 scenarios for the year 2030. The scenarios illustrate theoretical best cases for $\mathrm{P}$ management and were chosen taking into account (i) commonly mentioned strategies for circular food systems and (ii) the current plans and discussions on waste management in Brussels (Bortolotti et al., 2018b; IBGE, 2018b). For example, food waste valorization is currently investigated by the city authorities as an alternative to collecting them together with residual waste and incineration (Bortolotti et al., 2018b).

The baseline scenario (Base, Table 3) is simply a projection of the current situation into the future, accounting for population and visitors growth. We also apply a $20 \%$ reduction in the generation rate of avoidable food waste for all scenarios, since this is the target of the city's new 5-year plan on waste (IBGE, 2018b). We do not account for diet changes in our scenarios, as we do not expect diets to change substantially by 2030, given that Brussels is an already dense and culturally diverse city with a high per capita GDP (IBSA, 2015), which are known to be factors that are influential on the diet. What is more, dietary changes would probably influence $\mathrm{P}$ inputs in food production upstream the city, but not the amounts of $\mathrm{P}$ consumed and wasted within it (Metson et al., 2016); these upstream effects, although relevant, are outside the scope of the current study.

For the Food Waste Valorization scenario (FWV) we assume a complete diversion of food waste from the incinerator to anaerobic digestion and composting (90\% and $10 \%$ respectively). In the Sewage Sludge Utilization scenario (SSU) all sewage sludge from the two WWTPs is anaerobically digested and stabilized with lime, making it potentially reusable to agriculture. Lime conditioning is the final treatment step for the sludge from the treatment plants of Liège and Namur, after which it is reused in agriculture (AIDE, 2018; INASEP, 2018). Finally, CO is the combination scenario that accommodates both measures. Table 3 summarizes the assumptions for all four scenarios and presents more details on the variables and rationale behind them are given in the SI.

It is worth noting that the scenarios' purpose is neither to represent solutions that can be realistically implemented until 2030, nor to mirror precisely the current plans and wishes of the stakeholders' involved. They are simply a methodological device with the purpose of generating potential upper limits for phosphorus reuse rate or savings. These limits can be used as benchmarks against which progress towards a more circular food system can be measured.

Table 3 Scenarios: target year 2030, est. population in BCR : 1'356'000 inh. (FWV : Food Waste Valorization, SSU : Sewage Sludge Utilization, CO : Combination, AG : agriculture, NL : the Netherlands)

\begin{tabular}{llllll}
\hline & Base & FWV & SSU & CO & Destination \\
\hline Food waste reduction (avoidable FW) & $20 \%$ & $20 \%$ & $20 \%$ & $20 \%$ & NA \\
Share of food waste collected sent to incineration & $100 \%$ & $0 \%$ & $100 \%$ & $0 \%$ & NA \\
Share of FW collected digested anaerobically & $0 \%$ & $90 \%$ & $0 \%$ & $90 \%$ & AG Wallonia \\
Share of FW sent to compost & $0 \%$ & $10 \%$ & $0 \%$ & $10 \%$ & Brussels \\
Share of sludge reused in AG (both plants) & $0 \%$ & $0 \%$ & $100 \%$ & $100 \%$ & AG Wallonia \\
Share of sludge exported or to landfill & $100 \%$ & $100 \%$ & $0 \%$ & $0 \%$ & Landfill / DE \\
\hline
\end{tabular}




\subsubsection{Circularity Indicators}

One of the objectives of this work is to assess the circularity of the current food system in BCR and compare it with scenarios that are expected to increase this circularity. There is still neither a widely accepted definition on what circularity is (Kirchherr et al., 2017) nor consensus on how to measure it (EASAC, 2016; Moraga et al., 2019; Pauliuk, 2018), especially when the focus is on food or the bio-economy in general. For the purposes of our study, we chose to compare three different P-based indicators (Table 4), depending on whether the phosphorus is potentially reused or reusable: (i) within the administrative boundary of the city ('City Circularity'), (ii) in agriculture both within the city and outside the system boundary, corresponding to the concept of closed-loop recycling ('Food Circularity'), and (iii) anywhere, corresponding to the concept of open-loop recycling ('Weak Circularity'). In the third case, we account for all nutrients that are neither emitted in the environment nor landfilled. The three different circularity indicators are defined as:

- City Circularity : $\quad C C=\frac{\text { P reused within the city boundary }}{\text { total } P \text { input }}$

- Food Circularity : $F C=\frac{\text { Preused or reusable in agriculture }}{\text { total } P \text { input }}$

- Weak Circularity : $W C=\frac{P \text { reused }}{\text { total } \text { P input }}$

Table 4 Flows accounted for in the nominator of the three different circularity indicators used in this study. For the flow numbers refer to Figure 2, Table 1 and the SI.

\begin{tabular}{llccc}
\hline Flow & & City & Food & Weak \\
\hline F25 & Brussels Compost & $\mathrm{X}$ & - & $\mathrm{X}$ \\
F27 & Decentralised compost & $\mathrm{X}$ & $\mathrm{X}$ & $\mathrm{X}$ \\
F2119 & Treated sludge from N. WWTP to AG & - & $\mathrm{X}$ & $\mathrm{X}$ \\
F2218 & Treated sludge from S. WWTP to AG & - & $\mathrm{X}$ & $\mathrm{X}$ \\
F54 & Digestate from AD of org. waste & - & $\mathrm{X}$ & $\mathrm{X}$ \\
F31 & Incineration ashes & - & - & $\mathrm{X}$ \\
& Technosands and exported SS & - & - & - \\
\hline
\end{tabular}

These three simple metrics capture the extent of P-reuse in two different geographical scales (city and hinterland) and under three management scopes (city self-sufficiency, food system perspective and open-loop recycling). However, they are focused on reuse only: any upstream interventions, like the adoption of more efficient and less wasteful farming techniques, will have to happen outside the city's, and thus this study's, boundary. The sole focus on recycling has been justly criticized as too narrow-scoped to be used alone as a CE metric, e.g. (Parchomenko et al., 2019; Pauliuk, 2018), and we recognize that further research including the agricultural hinterlands in the system boundary will improve the metrics proposed here.

\section{Results}

\subsection{Phosphorus flows in 2014}

The phosphorus flows in BCR have a linear pattern (Figure 3). Almost 700 tonnes of $\mathrm{P}$ entered Brussels with the imported food products in 2014 (69\% of the total input), and the rest came from 
detergents (99 tP/yr), pet food (96 tP/yr), wastewater imports from Flanders (106 tP/a), industrial wastewater (15 tP/a) and fertilizers (16 tP/a). Most of the P inputs end up in the city's sewage system and are finally either released in the environment with the treated effluent $(139 \mathrm{tP} / \mathrm{yr})$ or captured in the sewage sludge. Sludge from the South WWTP is exported for incineration (107 tP/yr), whereas that from the North WWTP is processed into technosands and then used as cover material in landfills (455 tP/yr).

Phosphorus in the solid organic waste streams (food and green waste) represents around 17\% of the total input. Almost all food waste $(147 \mathrm{tP} / \mathrm{yr})$ and around $40 \%$ of the green waste $(11 \mathrm{tP} / \mathrm{yr})$ are collected in the white bags and incinerated together with residual waste (Figure $3 \mathrm{c}$ and $\mathrm{d}$ ). Another $12 \mathrm{tP} / \mathrm{yr}$ from green waste are sent to the composting facility of the city and around $8 \mathrm{tP} / \mathrm{yr}$ are exported through food and green waste to Flanders, to be treated anaerobically or composted. $160 \mathrm{tP} / \mathrm{yr}$, or $\sim 90 \%$ of all the $\mathrm{P}$ in the organic waste collected ends up in the incineration ashes and from there to the road construction industry in the Netherlands.

\subsection{Phosphorus and energy flows under different scenarios}

The baseline scenario is simply an extrapolation of the situation in 2014. As such, more than three quarters of the incoming phosphorus enter the city with food (Figure 4a) and is either discharged through treated wastewater in the environment (12\%), used in landfills through sewage sludge (67\%), or turned into incineration ashes (15\%). Imported food dominates the energy flows, too (Figure 4c): 5'300 TJ/yr enter the city through imported food, most of which are taken up by human metabolism. 1'200 TJ/yr of process energy (PE) are used for the storage and preparation of food at the household level. The energy content of the organic waste entering the MSW management system is around 1'000 TJ/yr for the baseline scenario. This energy is recovered as electricity (100 $\left.\mathrm{TJ}_{\mathrm{e}} / \mathrm{yr}\right)$ and heat (309 $\left.\mathrm{TJ} / \mathrm{yr}\right)$ in the incinerator.

In the FWV scenario, all food waste is assumed to be valorized through anaerobic digestion and further use of the digestate in agriculture. Through the composted digestate, $114 \mathrm{tP} / \mathrm{yr}$ can be potentially reintroduced into food production, from $6 \mathrm{tP} / \mathrm{yr}$ for the baseline (Figure 5a). Besides, the energetic valorization of the biogas produced during fermentation results in $116 \mathrm{TJ} / \mathrm{yr}$ of gross generated electricity, an increase of $+16 \%$, compared to the baseline (100 $\mathrm{TJ} / \mathrm{yr}$ ). If we account for the net electricity output, however, the MSWM contributes almost three times more electricity, compared to the baseline (114 TJe/yr versus $38 \mathrm{TJ} / \mathrm{yr}$, Figure 5b), thanks to the lower energy input requirements of an $\mathrm{AD}$ plant, compared to the incinerator. Due to the diversion of the organic waste from the incinerator, the amount of heat generated is drastically smaller for FWV.

The SSU scenario has the most drastic effect on the amount of $\mathrm{P}$ potentially reintroduced into agriculture (Figure 5a). When all the sewage sludge is conditioned and used in agriculture, instead of turned into technosands and landfilled, $674 \mathrm{tP} / \mathrm{yr}$ or almost $60 \%$ of the phosphorus input can be circulated back into the food system. This scenario has no effect on the energy flows, since the MSWM system is the same as for the baseline. The combined effects of FWV and SSU are illustrated with the combined scenario, CO. In that scenario, more than $800 \mathrm{tP} / \mathrm{a}$ can be circulated, while generating $116 \mathrm{TJ}_{\mathrm{e}} / \mathrm{yr}$ (Figure 4b, 5b). 


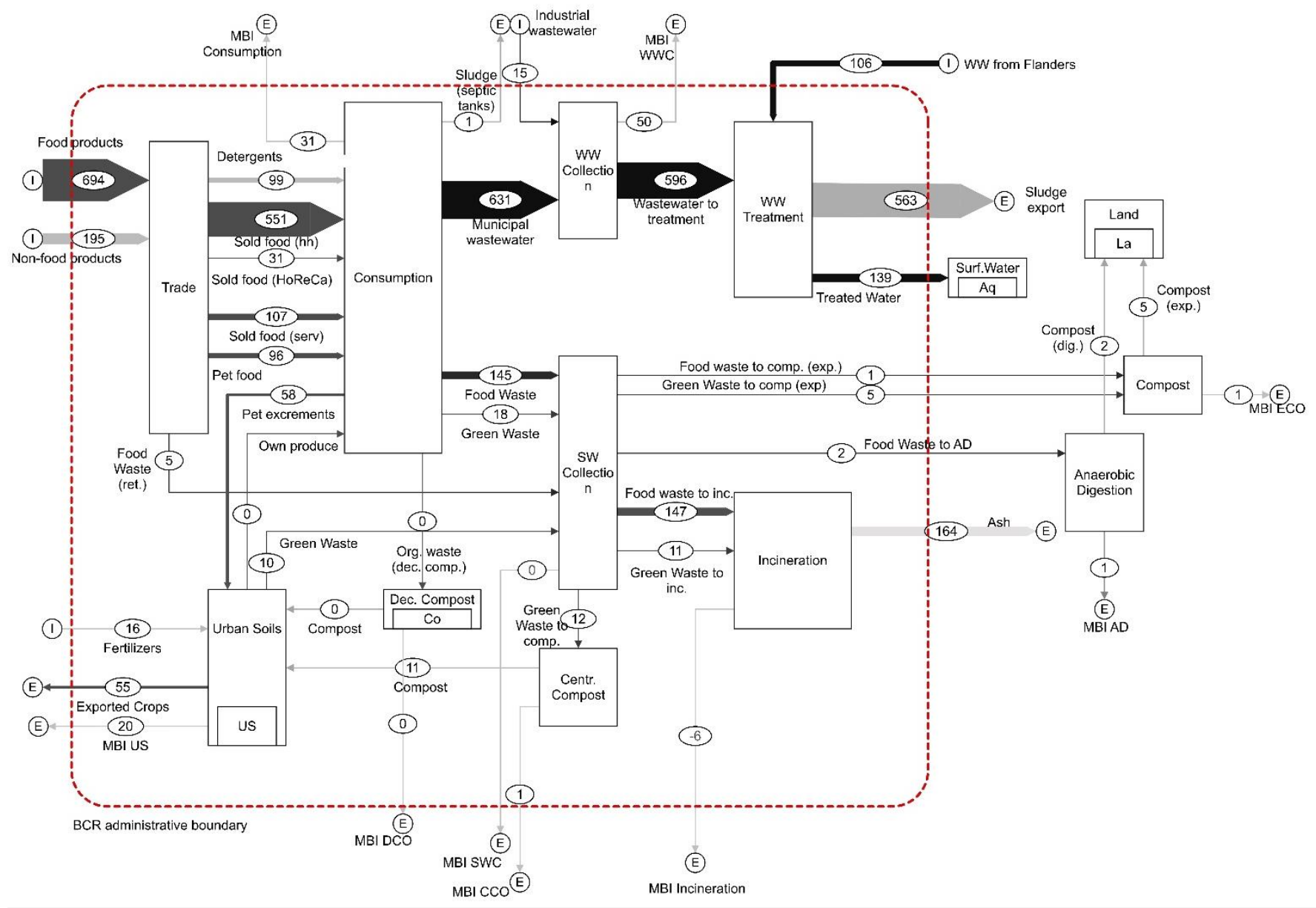

(a)

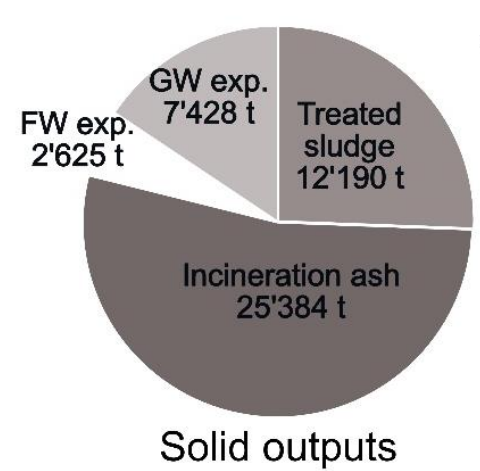

(b)

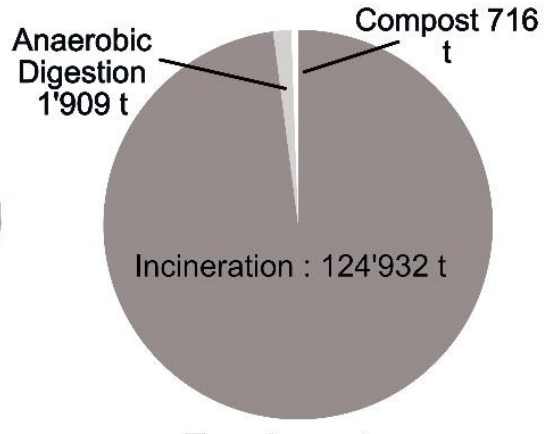

Food waste

(c)

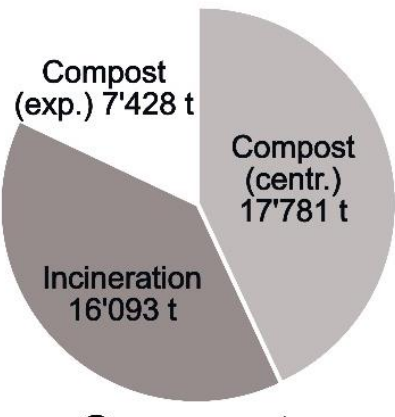

Green waste

(d)

Figure 3 Phosphorus flows in BCR for 2014 in tonnes P/year (a), distribution of total amounts of solid outputs (b) [in tonnes/year], and distribution of food (c), and green waste (d) according to treatment type [in tonnes/year]. Deviations from the numbers in the text are due to rounding. (MBI : Mass Balance Inconsistency, WW : Wastewater, WWC : Wastewater Collection, US : Urban Soils, SW : Solid Waste, DCO : Decentralized Compost, CCO : Centralized Compost, ECO : Exported Compost, FW : Food Waste, GW : Green Waste). 
baseline scenario (base)

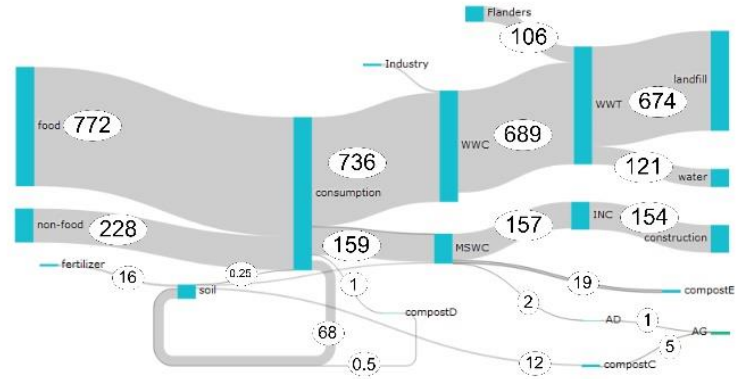

(a)

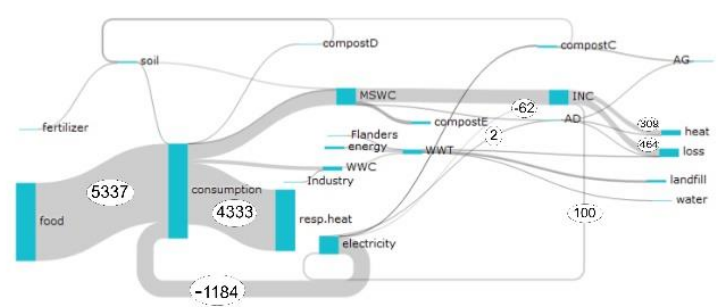

(c)

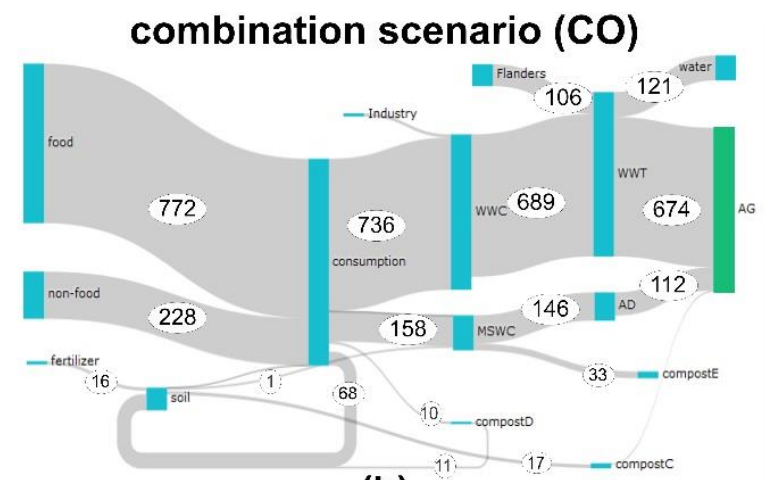

(b)

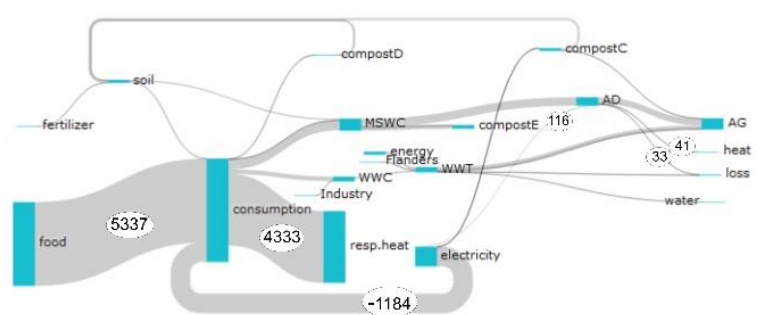

(d)

Figure 4 Sankey diagrams for the phosphorus (first row, in tonnes / year) and energy (second row, in TJ / year) flows in BCR for the baseline (left), and the combination (right) scenarios. Only values are for process energy and the total input energy are shown in the energy diagrams for better readability. Negative values indicate imports of process energy. WWC : wastewater collection, WWT : wastewater treatment, MSWC : municipal solid waste collection, INC : incineration, AG : agriculture, AD : anaerobic digestion, compostD: decentralised, compostC: centralised, compostE : exported

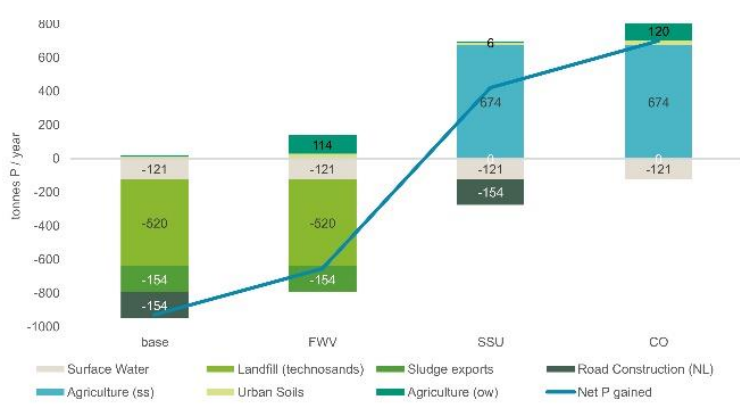

(a)

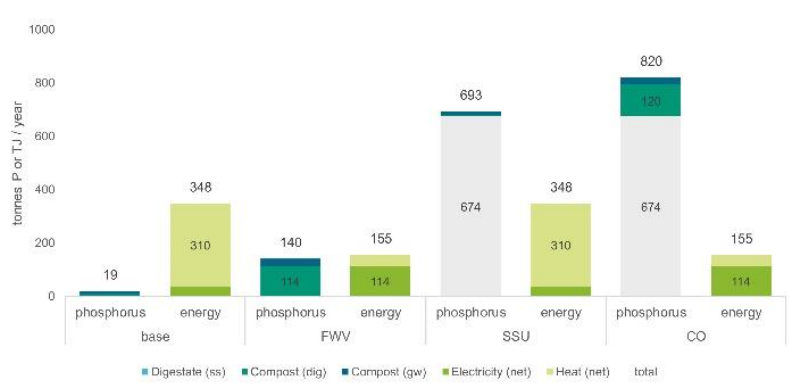

(b)

Figure 5 (a) Amounts of phosphorus outputs per destination and net $P$ gained (Preusable $-P_{\text {lost, }}$ in tP/yr) and (b) amounts of phosphorus (in tP/yr) potentially available for reuse and of net energy (in $\mathrm{TJ} / \mathrm{yr}$ ) recovered from the municipal waste management system (incineration or anaerobic digestion) for the different scenarios. ss: sewage sludge, dig: digestate, gw: green waste. 


\subsection{Levels of phosphorus circularity per scenario}

The degree of circularity of the system varies depending on the scenario and type of circularity (Figure 6). When all the potential alternative uses of the P-rich effluents are taken into account, a score of $14 \%$ 'weak circularity' is achieved for the baseline scenario. In this case, the reuse corresponds to the phosphorus amounts ending up in the road construction industry through the incineration ashes. On the other hand, the degree of phosphorus 'city circularity' that Brussels can achieve is persistently low, with a maximum of $2 \%$ of the $\mathrm{P}$ inputs reused within the city's boundaries for the FWV scenario. 'Food circularity' ranges from 0 for the baseline scenario to more than $70 \%$ for the theoretical case when all sewage sludge is used in agriculture and all food waste is diverted from the incinerator to an anaerobic digestion unit.

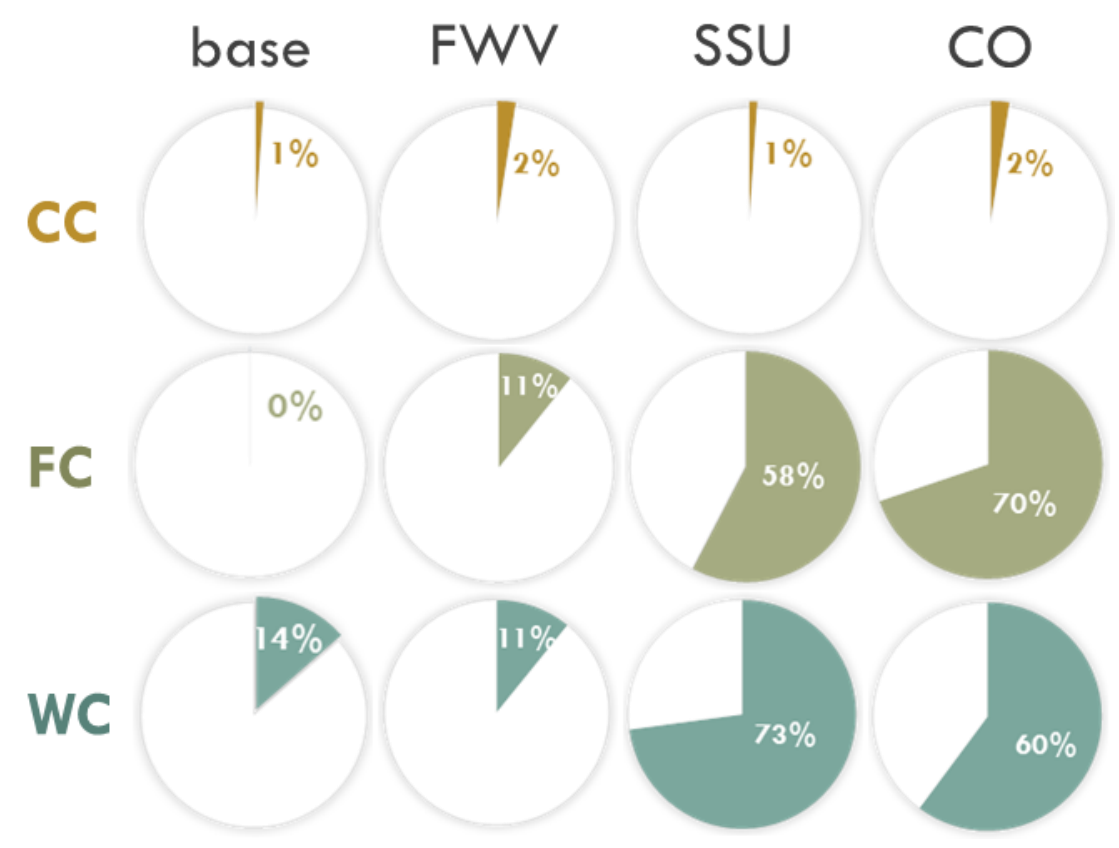

Figure 6 Phosphorus circularity indicators for each scenario: City Circularity (CC), Food Circularity (FC) and Weak Circularity (WC). For an explanation on the indicators and the acronyms of the scenarios, see text.

\section{Discussion}

Since the phosphorus 'city circularity' stays negligible across the scenarios, P-containing products will probably need to be transported for reuse outside of the city. For this reason, most of this section is dedicated to discussing parameters that can affect whether and where these potentially reusable $P$ flows will be reused, even outside our system boundary. We address two aspects: (i) the characteristics of the outflows as alternative products to synthetic fertilizer, and (ii) necessary conditions for their reuse outside the city boundary. We further put our results into context and we close an evaluation of our methodology and model. 


\subsection{Characteristics of output flows regarding their agricultural reuse}

The P-containing outputs vary according to scenario (Figure 5a). For the baseline, two are the main outputs: $520 \mathrm{tP} / \mathrm{yr}$ of technosands, used as covering material to landfills, and incineration ashes exported to the Dutch road construction sector (154 tP/yr). For FWV and SSU, two additional products occur: composted digestate (114 tP/yr for the FWV scenario) and treated sewage sludge (674 tP/yr for the SSU and CO scenarios), both of which are reusable in agriculture. Green waste compost is produced within the region in all scenarios, though in much smaller quantities than the other products: $12 \mathrm{tP} / \mathrm{yr}$ for the baseline, and SSU scenarios and $17 \mathrm{tP} / \mathrm{yr}$ for FWV and CO. The last three (treated sewage sludge, composted digestate and green waste compost) are the products that we consider reusable in agriculture and that we take into account to calculate the 'food circularity' of the system, based on their P-content.

Several parameters will affect whether these streams will indeed be reused or not; their demand and the legal framework governing their management are two crucial ones that are covered in the following section of this paper. Table 5 summarizes some properties of these products that we expect to affect the desirability and profitability of each scenario: (i) the P concentration of the flow; (ii) the plant availability of $\mathrm{P}$ in each product; (iii) their market price; and (iv) the net energy output of the treatment processes that generate each of the products.

Treated sludge (digested and dried) is by far the product with the highest $\mathrm{P}$ concentration. The concentration depends on the performance of the drying: in our case we assumed a total solids (TS) content of $90 \%$ in dry sludge, according to the current performance of the filter press in the N.WWTP (Chauzy et al., 2010). Even with a more moderate assumption of $35 \%$ solid content, the sludge remains the most concentrated stream. What is more, plants can take up $\mathrm{P}$ easier from digestate than from compost (Table 5) and digestate is currently sold at a higher price than compost. Sewage sludge digestate is therefore the most valuable of the $\mathrm{P}$ effluents from Brussels.

Table 5 Characteristics of compost and digestate (gw: green waste, dig. : digestate, ss : sewage sludge). For the estimation of the fuel needed for transport we assume transport with lorries at $2 \mathrm{MJ} / \mathrm{tkm}$.

\begin{tabular}{|c|c|c|c|c|}
\hline & Compost gw & Compost dig. & Digestate ss & Source \\
\hline Concentration $[\mathrm{kgP} / \mathrm{tn}]$ & 1.2 & 2.0 & 21.4 & This study \\
\hline Plant availability [\%] & $50 \%$ & $50 \%$ & $90 \%$ & $(1),(2)$ \\
\hline Price $[€ /$ tn $]$ & 8 & 8 & 16 & $(3),(4)$ \\
\hline Fuel for $50 \mathrm{~km}$ transport [L/kgP] & 2.3 & 1.4 & 0.1 & this study and (5) \\
\hline Fuel for $50 \mathrm{~km}$ transport $[\mathrm{kWh} / \mathrm{kgP}]$ & 22.5 & 13.9 & 1.0 & \\
\hline $\begin{array}{l}\text { Electricity generation from process } \\
{\left[\mathrm{kWh}_{\text {net }} / \mathrm{kgP}\right]}\end{array}$ & -14 & 462 & 274 & This study \\
\hline
\end{tabular}

${ }^{(1)}$ (Hamilton et al., 2017), ${ }^{(2)}$ (Haupt et al., 2018) ${ }^{(3)}$ (Bruxelles-Compost, 2014), ${ }^{(4)}$ (Vlaco, 2016), ${ }^{(5)}$ (EEA, 2016)

The major disadvantage of sewage sludge as a secondary $\mathrm{P}$ source is its potentially high concentration of heavy metals and pharmaceuticals. Heavy metals in urban wastewater can be due to atmospheric deposition, street runoff, but mainly the presence of industrial effluents in the sewer system (Angelidis and Gibbs, 1989; Sperling, 2007). Since hardly any industries operate within BCR and only the South WWTP receives some industrial wastewater ${ }^{1}$, it is unlikely that heavy

\footnotetext{
${ }^{1} 30 \%$ of its total according to (IBGE, 2017b), corresponding to $7.5 \%$ of the total water treated in the region.
} 
metal concentrations in the sludge will surpass the legal thresholds for agricultural use adopted by the region in 1993 (Bruxelles-Capitale, 1993), which is still valid until this day. According to recent measurements (Brion, 2019) the heavy metal concentrations of the mineralized sludge (technosands) are close to the threshold values for lead and nickel and well above thresholds for zinc and copper. The fresh, dried sludge from the South plant performs better, with all metals being well below the legal thresholds. Since the mineralization process in the North WWTP reduces the mass of the sludge drastically by oxidizing all organic matter, we can expect that the concentrations of fresh, dried sludge from the North WWTP would be lower and probably closer to the ones from the South WWTP (Brion, 2019, personal communication). At the moment, there is not much information on the concentrations of micro-pollutants, like pharmaceuticals and hormones.

\subsection{Use of urban effluents in and around BCR}

BCR has $\sim 1$ ' 850 ha of arable land that produce mostly winter wheat, sugar beets and potatoes, destined for the processing industry outside the city. Next to the conventional agricultural activity, some of the vegetables, mushrooms, and fruits that Brussels inhabitants eat are cultivated in community and private gardens and in a few professional horticulture urban farms. The region supports these initiatives through its 'Good Food' strategy (Ronsmans, 2015) and the number of gardens and micro-farms has been rising in the past four years. rThe role of vegetables grown within the city, however, remains marginal in covering the demand: local professional farms cover hardly $0.1 \%$ of the current demand (Boutsen et al., 2018). In our model we adopted the assumption that a maximum $1 \%$ of the demand for fruits and vegetable can be provided from within the region (EcoRes sprl et al., 2015, p. 95). Still, the role of locally produced food remains negligible in the $\mathrm{P}$ cycle: around $0.5 \mathrm{tP} / \mathrm{a}$ come from locally grown fruits and vegetables, a tiny fraction of the 770 tP/a imported through food.

The inability of the agricultural production within BCR to absorb the P in the city's waste streams means that the P-rich urban effluents will need to be exported and valorized in the neighboring provinces, or even further away in Belgium and abroad. Exports will become easier after the new European Fertilizers Directive, which accounts for organic fertilizers, will come into force in 2022 (EC, 2018). At the same time, the Flemish and Walloon regions generate their own P-rich flows, that will probably be given priority over imported ones. The livestock sector in Flanders especially, is a big manure producer and exporter, with strict regulations in the region regarding the nutrient application rates to the soil (Kristel Vandenbroek, 2017). Consequently, a detailed evaluation of the nutrient flows and needs in the agri-food system around Brussels is indispensable in order to locate possible sites for the reuse of secondary $\mathrm{P}$.

The focus of this paper is phosphorus, and so much of the discussionrefers to the fertilization value of treated organic waste. Compost and digestate are, however, products different from mineral fertilizer and manure: although they release nutrients in the soil, their primary purpose is often soil conditioning. So, even if we can say that the $>650 \mathrm{tP} / \mathrm{yr}$ available in the system's outputs can theoretically cover the whole P-demand for the two Brabant regions (assuming 100\% substitution) or around $10 \%$ of the whole demand for Belgium, future analyses must be more 
nuanced. It is, for example, expected that small organic urban and peri-urban farms will show a higher interest in using compost produced in the city than big conventional farms. What is more, products from a city's organic waste management system can be valorized for reasons other than food production, e.g. landscaping and ornamental horticulture. Such uses are excluded from the discussion in this study, since the focus is on the food system and 'closed-loop' recycling of urban organic waste; nonetheless, these alternative uses can be substantial components of a more sustainable phosphorus management in urban areas.

\subsection{Phosphorus versus energy}

An underlying hypothesis behind this study has been that, if Brussels makes more phosphorus available for reuse through the implementation of Circular Economy inspired strategies, energy expenditure will rise, due to additional treatment steps in the municipal solid waste and urban water management systems. In Figure $5 \mathrm{~b}$ we can see that the total net energy output in each scenario is indeed either lower or the same as for the baseline. The main reason for this reduction is losing part of the heat generated in the incinerator by diverting the waste to an anaerobic digester (FWV). The heat from the incinerator is currently used on site for heating the different facilities and is partially converted to electricity (IBGE, 2018c). However, in the case where we only account for electricity and not heat, the FWV scenario by far outperforms all others. This indicates that implementing a common food waste valorization strategy (digestion of food waste) increases both the amount of potentially reusable $\mathrm{P}$ available, and the amount of net electricity recovered. On the other hand, the SSU scenario has an important effect on the amounts of P potentially available for reuse, but none at all on the net energy recovered, compared with the baseline (Figure $5 b)$. This is because anaerobic digestion with energy recovery from biogas is already part of the baseline scenario. Besides, all energy generated in the WWTPs is consumed on-site.

As a consequence, we see a synergetic effect between $\mathrm{P}$ recoverable and net electricity recovered, albeit a weak one. Further, it is worth putting the numbers into perspective, especially if the results are used to inform policy: the total net electricity production for the scenarios ranges from $38-114 \mathrm{TJ}_{\mathrm{e}} / \mathrm{yr}$ or $10-32 \mathrm{GWh}_{\mathrm{e}} / \mathrm{yr}$. Even the high ends of these ranges represent a tiny fraction of both the total energy consumption within BCR and the residential energy consumption, which in 2016 were more than 20’000 GWh/yr and 7'600 GWh/yr respectively (IBGE, 2018c). Most of the residential energy consumption comes from natural gas and only $17 \%$ (1'313 GWhe/yr) from electricity. This means that even for the ideal scenario where all food waste in BCR would be collected separately and valorized through anaerobic digestion, the electricity generated would cover a theoretical $3 \%$ of the total electricity demand of the households in Brussels, or $0.2 \%$ of the total energy demand in the region. For comparison, the national target for Belgium is to achieve $13 \%$ of the gross final energy consumption coming from renewables by 2020; the share of BCR in achieving this target was set to $0.073 \mathrm{Mtep}(\sim 850 \mathrm{GWh})$. 


\subsection{Methodological considerations}

In order to study the food system of Brussels Capital Region, we used the Region's administrative boundary as the system boundary. The focus has thus been on downstream solutions that are under the direct control of the Region's authorities, i.e. wastewater and solid organic waste management. The agricultural hinterland that produces the food consumed in Brussels was not included in the system. This means that we have not accounted for inputs from mineral fertilizers and manure, which are typically the largest phosphorus flows in a food system. In addition, strategies like food waste avoidance, which would result in large phosphorus savings upstream and thus larger savings in total, have not been included in the scenario analysis. This calls for a careful interpretation of our scenario results, and for future research to address this shortcoming by including food production in the system boundary.

As is usually the case for MFA studies, data are coming from different sources of varying quality. A range of methods was used to estimate the flows, from actual statistics and facilityspecific data (e.g. mixed household waste, wastewater quantities and characteristics) to modelling based on generic literature data (e.g. sludge treatment). Despite this, the Mass Balance Inconsistencies typically represent a small fraction of total input in a process. An exception is the MBI for Urban Soils (Figure 3). The process "Urban Soils" was modeled quite rough, so it is possible that most of the $\mathrm{P}$ accounted for in the MBI will either accumulate in the soil, or contribute to the growth of plants other than the agricultural crops. A more detailed accounting of the fate of $\mathrm{P}$ in the urban soil will allow to better understand the capacity of the soil to take up more $\mathrm{P}$ and under what conditions.

Lack of readily available data was also the reason why the food industry is not included in the system. In fact, Zeller and colleagues (2019) estimate that up to 25'000 tons of organic waste were generated in Brussels in 2014. Assuming average P and energy contents of $0.15 \%$ (Coppens et al., 2016) and $13 \mathrm{MJ} / \mathrm{kg}$ (Bernstad and la Cour Jansen, 2011), industrial food waste could have contributed an extra $40 \mathrm{tP} / \mathrm{yr}$ and $340 \mathrm{TJ} / \mathrm{yr}$ to the MSWM sub-system. This is more than $20 \%$ of the phosphorus we account for currently, and indicates that food industry is potentially an important part of the system. However, import data for BCR are tricky to collect and interpret, as illustrated in detail in (EcoRes sprl et al., 2015), so that the estimation of the inputs would introduce additional uncertainties. For this reason, we left food processing out of the system.

Finally, the scenarios are ideal best cases, a methodological device meant to provide information on maximum theoretical amounts of $\mathrm{P}$ potentially reusable. These values can be used, for example, as targets or benchmarks against which progress towards better P-management and a more circular food system can be measured. Realistic and implementable scenarios for the organic waste system in Brussels have been generated within the Opération Phosphore project and can be found in (Bortolotti et al., 2019, 2018b; De Muynck et al., 2019). 


\section{Conclusions and outlook}

In this paper we analyzed the phosphorus and energy flows in the food system of Brussels Capital Region and assessed the impacts of 3 alternative, theoretical scenarios on these flows: food waste valorization, sewage sludge utilization and a combination of the two. Brussels has a nutrient metabolism typical of a city: almost all $\mathrm{P}$ that enters through imported food ends up in the sewage sludge and from there to landfill. Diverting these amounts of phosphorus from the landfill to agriculture has the potential to greatly increase the circularity of the city's food system. The impact of the alternative scenarios on the energy flows is not as clean-cut as for P. Yet, energy recovery from organic waste can only marginally contribute to covering the city's energy demand.

Our study contributes to the literature on urban phosphorus flows and urban food systems, by providing a case study for the city of Brussels, linking food to phosphorus and energy flows in a multi-resource approach and exemplifying ways to create and measure food system circularity in an urban context. Our results indicate that the options for closing loops in the food system of Brussels are limited within the city-region's boundary. The P-rich urban effluents have to re-enter the food system somewhere outside the borders and this means that the connection of the city with its local hinterland needs to be strong, in a mutual beneficial relationship. Studying this connection on different scales (local-national-global) can offer a more concrete and substantial view on how circular urban food systems can be designed and implemented.

The information on the amounts of resources flowing in-, out-, and within the city, is an indispensable first step to design policy interventions. Such interventions will also depend, however, on the views and aspirations of different stakeholders, the legal framework, the prioritizing of different goals etc. This holds even more true for Brussels and Belgium, where governance is fragmented and the regulatory landscape complex. Understanding these factors can thus offer a whole different level of insight into the system and the need for integrating such knowledge into urban metabolism research is widely recognized.

\section{Acknowledgements}

We would like to thank Kato Van Ruymbeke for proofreading this article. The study was completed within the SUSPLACE project, which received funding from the European Union's Horizon 2020 research and innovation programme under the Marie Skłodowska-Curie grant agreement No 674962. 


\section{References}

ABP, n.d. Rapports annuels [WWW Document]. URL https://www.arp-gan.be/fr/qui-sommesnous/rapports-annuels.html (accessed 5.29.19).

AIDE, 2018. Exploitation des stations d'épuration. Déclaration environnementale 2018.

Angelidis, M., Gibbs, R.J., 1989. Chemistry of metals in anaerobically treated sludges. Water Res. 23, 29-33. https://doi.org/10.1016/0043-1354(89)90057-2

Anon, 2016. Programme régional en economie circulaire 2016-2020. Mobiliser les ressources et minimiser les richesses perdues: pour une économie régionale innovante.

Aquiris, n.d. AQUIRIS en chiffres [WWW Document]. URL https://www.aquiris.be/quelqueschiffres.php (accessed 6.25.19).

AQUIRIS, n.d. Le traitement des eaux. Le procédé d'épuration [WWW Document]. URL http://www.aquiris.be/traitement-eaux.php (accessed 5.4.18).

Athanassiadis, A., Bouillard, P., Crawford, R.H., Khan, A.Z., 2016. Towards a Dynamic Approach to Urban Metabolism: Tracing the Temporal Evolution of Brussels' Urban Metabolism from 1970 to 2010. J. Ind. Ecol. https://doi.org/10.1111/jiec.12451

Baccini, P., Brunner, P.H., 2012. Metabolism of the anthroposphere : analysis, evaluation, design, 2nd ed. MIT Press, Cambridge, MA.

Bernstad, A., la Cour Jansen, J., 2011. A life cycle approach to the management of household food waste - A Swedish full-scale case study. Waste Manag. 31, 1879-1896. https://doi.org/10.1016/j.wasman.2011.02.026

Boldrin, A., Christensen, T.H., 2010. Seasonal generation and composition of garden waste in Aarhus (Denmark). Waste Manag. $\quad$ 30, 551-557. https://doi.org/10.1016/j.wasman.2009.11.031

Bortolotti, A., Aragone, A., Athanassiadis, A., Muynck, S. De, Kampelmann, S., 2018a. Potentiel des biodéchets collectables en Région de Bruxelles-Capitale. Rapport final.

Bortolotti, A., Aragone, A., Claeys, M., Grulois, G., Dierick, B., Smis, J., Mets, S. De, Six, L., Monic, D., 2018b. Étude De Faisabilité Stratégique d'implementation d'une unité biométhanisation en Région de Bruxelles-Capitale.

Bortolotti, A., Kampelmann, S., De Muynck, S., Papangelou, A., Zeller, V., 2019. Conditions and concepts for interdisciplinary urban metabolism research-the case of an inter-project collaboration on biowaste. Flux 116-117, 70-85.

Boutsen, R., Maughan, N., Visser, M., 2018. Evaluation de la production agricole primaire professionnelle en Région de Bruxelles Capitale.

Brion, N., 2019. Preliminary results of SUBLIMUS project (INNOVIRIS Bridge 2019).

Bruxelles-Capitale, R. de, 1993. 15 Juillet 1993 - Arrêté du Gouvernement de la Région de Bruxelles-Capitale relatif à l'utilisation des boues d'épuration en agriculture. Belgium.

Bruxelles-Compost, 2014. Conditions generales d'apport de déchets verts à Bruxelles Compost.

Cano, R., Pérez-Elvira, S.I., Fdz-Polanco, F., 2015. Energy feasibility study of sludge pretreatments: A review. Appl. Energy 149, 176-185. https://doi.org/10.1016/j.apenergy.2015.03.132

Chauzy, J., Martin, J., Cretenot, D., Rosiere, J., 2010. Wet Air Oxidation of Municipal Sludge: Return Experience of the North Brussels Waste Water Treatment Plant. Water Pract. Technol. 
5, 1-8. https://doi.org/10.2166/wpt.2010.003

Chowdhury, R.B., Moore, G.A., Weatherley, A.J., Arora, M., 2014. A review of recent substance flow analyses of phosphorus to identify priority management areas at different geographical scales. Resour. Conserv. Recycl. https://doi.org/10.1016/j.resconrec.2013.10.014

Coppens, J., Meers, E., Boon, N., Buysse, J., Vlaeminck, S.E., 2016. Follow the N and P road: High-resolution nutrient flow analysis of the Flanders region as precursor for sustainable resource management. Resour. Conserv. Recycl. 115, 9-21. https://doi.org/10.1016/j.resconrec.2016.08.006

Cordell, D., Drangert, J.O., White, S., 2009. The story of phosphorus: Global food security and food for thought. Glob. Environ. Chang. 19, 292-305. https://doi.org/10.1016/j.gloenvcha.2008.10.009

De Muynck, S., Stephan Kamplemann, Dávila, F., 2019. Opération Phosphore. Rapport Scientifique \#2.

EASAC, 2016. Indicators for a circular economy. Halle, Germany.

EC, 2018. Circular Economy: Agreement on Commission proposal to boost the use of organic and waste-based fertilisers.

EcoRes sprl, ICEDD, BATir (ULB), 2015. Métabolisme de la Région de Bruxelles-Capitale: identification des flux, acteurs et activités économiques sur le territoire et pistes de réflexion pour l'optimisation des ressources. Bruxelles.

EEA, 2016. Indicator 20: Energy and CO2 intensity [WWW Document]. Energy Effic. URL https://www.eea.europa.eu/publications/ENVISSUENo12/page027.html (accessed 7.12.19).

EMF, 2019. Cities and circular economy for food, Ellen Macarthur Foundation.

Esculier, F., Le Noë, J., Barles, S., Billen, G., Créno, B., Garnier, J., Lesavre, J., Petit, L., Tabuchi, J., 2018. The biogeochemical imprint of human metabolism in Paris Megacity: A regionalized analysis of a water-agro-food system. J. Hydrol. https://doi.org/10.1016/j.jhydrol.2018.02.043

Fisgativa, H., Tremier, A., Dabert, P., 2016. Characterizing the variability of food waste quality: A need for efficient valorisation through anaerobic digestion. Waste Manag. 50, 264-274. https://doi.org/10.1016/j.wasman.2016.01.041

Goldstein, B., Birkved, M., Fernández, J., Hauschild, M., 2017. Surveying the Environmental Footprint of Urban Food Consumption. J. Ind. Ecol. 21, 151-165. https://doi.org/10.1111/jiec. 12384

Hamilton, H.A., Brod, E., Hanserud, O., Müller, D.B., Brattebø, H., Haraldsen, T.K., 2017. Recycling potential of secondary phosphorus resources as assessed by integrating substance flow analysis and plant-availability. Sci. Total Environ. 575, 1546-1555. https://doi.org/10.1016/j.scitotenv.2016.10.056

Hamilton, H.A., Peverill, M.S., Müller, D.B., Brattebø, H., 2015. Assessment of Food Waste Prevention and Recycling Strategies Using a Multilayer Systems Approach. Environ. Sci. Technol. 49, 13937-13945. https://doi.org/10.1021/acs.est.5b03781

Haupt, M., Kägi, T., Hellweg, S., 2018. Life Cycle Inventories of Waste Management Processes. Data Br. 54, 1-17. https://doi.org/10.1016/j.dib.2018.05.067

IBGE, 2019. Les tables annuelles des données du bilan de 1990 à 2017. 
IBGE, 2018a. Performances épuratoires des stations d'épuration.

IBGE, 2018b. Plan de gestion des ressources et des déchets.

IBGE, 2018c. Bilan Energetique de la Région de Bruxelles-Capitale.

IBGE, 2017a. BILAN ENERGETIQUE DE LA REGION DE BRUXELLES-CAPITALE 2015.

IBGE, 2017b. Plan de gestion de l'eau de la region de Bruxelles-Capitale 2016-2021. Bruxelles.

IBGE, 2015. Bilan Energetique de la région de Bruxelles-Capitale 2013. Bilans de 1'industrie et du secteur tertiaire et Bilan global.

IBGE, 2012. Production et gestion des boues et sédiments en région de Bruxelles-Capitale.

IBSA, 2015. Mini-Bru 2015. La Région Bruxelles-Capitale en chiffres.

INASEP, 2018. Déclaration environnementale annuelle. Résultats 2017.

Jensen, M.B., Møller, J., Scheutz, C., 2016. Comparison of the organic waste management systems in the Danish-German border region using life cycle assessment (LCA). Waste Manag. 49, 491-504. https://doi.org/10.1016/j.wasman.2016.01.035

Kalmykova, Y., Harder, R., Borgestedt, H., Svanäng, I., 2012. Pathways and Management of Phosphorus in Urban Areas. J. Ind. Ecol. 16, 928-939. https://doi.org/10.1111/j.15309290.2012.00541.x

Kirchherr, J., Reike, D., Hekkert, M., 2017. Conceptualizing the circular economy: An analysis of 114 definitions. Resour. Conserv. Recycl. 127, 221-232. https://doi.org/10.1016/j.resconrec.2017.09.005

Kristel Vandenbroek, 2017. ECN Country Report 2015. Belgium (Flanders).

Le Noë, J., Billen, G., Garnier, J., 2017. How the structure of agro-food systems shapes nitrogen, phosphorus, and carbon fluxes: The generalized representation of agro-food system applied at the regional scale in France. Sci. Total Environ. 586, 42-55. https://doi.org/10.1016/j.scitotenv.2017.02.040

Li, S., Yuan, Z., Bi, J., Wu, H., 2010. Anthropogenic phosphorus flow analysis of Hefei City, China. Sci. Total Environ. 408, 5715-5722. https://doi.org/10.1016/j.scitotenv.2010.08.052

Liang, S., Qu, S., Zhao, Q., Zhang, X., Daigger, G.T., Newell, J.P., Miller, S.A., Johnson, J.X., Love, N.G., Zhang, L., Yang, Z., Xu, M., 2019. Quantifying the Urban Food-Energy-Water Nexus: The Case of the Detroit Metropolitan Area. Environ. Sci. Technol. 53, 779-788. https://doi.org/10.1021/acs.est.8b06240

Lin, T., Wang, J., Bai, X., Zhang, G., Li, X., Ge, R., Ye, H., 2016. Quantifying and managing food-sourced nutrient metabolism in Chinese cities. Environ. Int. 94, 388-395. https://doi.org/http://dx.doi.org/10.1016/j.envint.2016.04.036

Ma, L., Guo, J., Velthof, G.L., Li, Y., Chen, Q., Ma, W., Oenema, O., Zhang, F., 2014. Impacts of urban expansion on nitrogen and phosphorus flows in the food system of Beijing from 1978 to 2008. Glob. Environ. Chang. 28, 192-204. https://doi.org/10.1016/j.gloenvcha.2014.06.015

Metson, G.S., Bennett, E.M., 2015. Phosphorus cycling in Montreal's food and urban agriculture systems. PLoS One 10, 1-18. https://doi.org/10.1371/journal.pone.0120726

Metson, G.S., Cordell, D., Ridoutt, B., 2016. Potential Impact of Dietary Choices on Phosphorus Recycling and Global Phosphorus Footprints: The Case of the Average Australian City. Front. Nutr. 3, 35. https://doi.org/10.3389/fnut.2016.00035 
Möller, K., Oberson, A., Bünemann, E.K., Cooper, J., Friedel, J.K., Glæsner, N., Hörtenhuber, S., Løes, A.-K., Mäder, P., Meyer, G., Müller, T., Symanczik, S., Weissengruber, L., Wollmann, I., Magid, J., 2018. Chapter Four - Improved Phosphorus Recycling in Organic Farming: Navigating Between Constraints, in: Sparks, D.L.B.T.-A. in A. (Ed.), Advances in Agronomy. Academic Press, p. 159-237. https://doi.org/https://doi.org/10.1016/bs.agron.2017.10.004

Moraga, G., Huysveld, S., Mathieux, F., Blengini, G.A., Alaerts, L., Van Acker, K., de Meester, S., Dewulf, J., 2019. Circular economy indicators: What do they measure? Resour. Conserv. Recycl. 146, 452-461. https://doi.org/10.1016/j.resconrec.2019.03.045

Nesme, T., Withers, P.J.A., 2016. Sustainable strategies towards a phosphorus circular economy. Nutr. Cycl. Agroecosystems 104, 259-264. https://doi.org/10.1007/s10705-016-9774-1

Nubel, 2018. Internubel - database of trade names [WWW Document]. URL http://www.internubel.be/

Ost, C., 2015. Lieu de consommation des repas, in: Lebacq, T., Teppers, E. (Eds.), Enquête de Consommation Alimentaire 2014-2015. Rapport 1. WIV-ISP, Bruxelles.

Ott, C., Rechberger, H., 2012. The European phosphorus balance. Resour. Conserv. Recycl. 60, 159-172. https://doi.org/10.1016/j.resconrec.2011.12.007

Parchomenko, A., Nelen, D., Gillabel, J., Rechberger, H., 2019. Measuring the circular economy - A Multiple Correspondence Analysis of 63 metrics. J. Clean. Prod. 210, 200-216. https://doi.org/10.1016/j.jclepro.2018.10.357

Pauliuk, S., 2018. Critical appraisal of the circular economy standard BS 8001:2017 and a dashboard of quantitative system indicators for its implementation in organizations. Resour. Conserv. Recycl. 129, 81-92. https://doi.org/10.1016/j.resconrec.2017.10.019

Qiao, M., Zheng, Y.M., Zhu, Y.G., 2011. Material flow analysis of phosphorus through food consumption in two megacities in northern China. Chemosphere 84, 773-778. https://doi.org/10.1016/j.chemosphere.2011.01.050

RDC-Environment, 2014. Inventaire et analyse des données existantes en matière d'offre alimentaire en Région de Bruxelles-Capitale.

REEW, 2018. Consommation d'engrais en agriculture [WWW Document]. État l'environnement Wallon. URL http://etat.environnement.wallonie.be/contents/indicatorsheets/AGRI 5.html (accessed 6.12.19).

Ridder, K. De, Bel, S., Brocatus, L., Cuypers, K., Lebacq, T., Moyersoen, I., Ost, C., Teppers, E., 2016. La consommation alimentaire. Rapport 4, in: Bel, S., Tafforeau, J. (Eds.), Enquête de Consommation Alimentaire 2014-2015. WIV-ISP, Bruxelles.

RIVM, 2016. NEVO online version 2016/5.0 [WWW Document]. URL https://nevoonline.rivm.nl/

Robinet, P., 2019. Interview with Philip Robinet 08/04/2019.

Rodríguez-Pose, A., 2008. The Rise of the "City-region" Concept and its Development Policy Implications. Eur. Plan. Stud. 16, 1025-1046. https://doi.org/10.1080/09654310802315567

Ronsmans, M., 2015. Good food strategy. Towards a sustainable food system in the BrusselsCapital Region.

SBGE, 2017. Rapport d'activités 2016.

SBGE, n.d. Documents [WWW Document]. URL 
http://www.sbge.be/fr/infos_documents_fr.html (accessed 5.29.19).

Schmid Neset, T.S., Bader, H.P., Scheidegger, R., Lohm, U., 2008. The flow of phosphorus in food production and consumption - Linköping, Sweden, 1870-2000. Sci. Total Environ. 396, 111-120. https://doi.org/10.1016/j.scitotenv.2008.02.010

Smil, V., 2000. Phosphorus in the Environment: Natural Flows and Human Interferences. Annu. Rev. Energy Environ. 25, 53-88. https://doi.org/10.1146/annurev.energy.25.1.53

Sperling, M. von, 2007. Wastewater characteristics, treatment and disposal. IWA PUblishing.

Statbel, 2018. Enquête sur le budget des ménages 2012-2014-2016. Possession biens durables Royaume et régions.

StatBel, 2014. Chiffres Agricoles 2014 - Tableau A.

Theobald, T.F.H., Schipper, M., Kern, J., 2016. Regional phosphorus flows Berlin-Brandenburg, a regional flow analysis. Resour. Conserv. Recycl. 112, 1-14. https://doi.org/10.1016/j.resconrec.2016.04.008

Treadwell, J.L., Clark, O.G., Bennett, E.M., 2018. Dynamic simulation of phosphorus flows through Montreal's food and waste systems. Resour. Conserv. Recycl. 131, 122-133. https://doi.org/10.1016/j.resconrec.2017.12.018

Villarroel Walker, R., Beck, M.B., 2012. Understanding the metabolism of urban-rural ecosystems. Urban Ecosyst. 15, 809-848. https://doi.org/10.1007/s11252-012-0241-8

Villarroel Walker, R., Beck, M.B., Hall, J.W., Dawson, R.J., Heidrich, O., 2014. The energywater-food nexus: Strategic analysis of technologies for transforming the urban metabolism. J. Environ. Manage. 141, 104-115. https://doi.org/10.1016/j.jenvman.2014.01.054

Vlaco, 2016. Ecologische en economische voordelen digestaat.

Vlaco, n.d. Gemiddelde samenstelling van Vlaco-compost [WWW Document]. URL https://www.vlaco.be/compost-gebruiken/wat-is-compost/gemiddelde-samenstelling-vanvlaco-compost (accessed 6.27.19).

VLM, 2014. Voortgangsrapport Mestbank 2013.

Withers, P.J.A., Doody, D.G., Sylvester-Bradley, R., 2018. Achieving Sustainable Phosphorus Use in Food Systems through Circularisation. Sustain. 10, 1-17. https://doi.org/10.3390/su10061804

WRAP, 2016. Estimates of Food Surplus and Waste Arisings in the UK 1-13.

Wu, J., Franzén, D., Malmström, M.E., 2016. Anthropogenic phosphorus flows under different scenarios for the city of Stockholm, Sweden. Sci. Total Environ. 542, 1094-1105. https://doi.org/10.1016/j.scitotenv.2015.09.024

Zeller, V., Towa, E., Degrez, M., Achten, W.M.J., 2019. Urban waste flows and their potential for a circular economy model at city-region level. Waste Manag. 83, 83-94. https://doi.org/10.1016/j.wasman.2018.10.034 